In addition, $\mathrm{HCQ}$ was associated with a $34 \%$ reduction in antidsDNA among AAs, but no significant reduction among CAs.

Table. Impact of treatment with $\mathrm{HCQ}$ on the odds of being positive for immunologic markers

\begin{tabular}{|c|c|c|c|c|c|c|}
\hline Clinical marker & $\begin{array}{l}\text { All Patients } \\
\qquad(\mathrm{n}=951)\end{array}$ & & $\begin{array}{c}\text { Caucasian } \\
\text { Americans } \\
(\mathrm{n}=462)\end{array}$ & & $\begin{array}{c}\text { African } \\
\text { Americans } \\
(\mathrm{n}=409)\end{array}$ & \\
\hline & $\begin{array}{l}\text { Odds Ratio } \\
(95 \% \mathrm{Cl})\end{array}$ & P-value & $\begin{array}{l}\text { Odds Ratio } \\
(95 \% \mathrm{Cl})\end{array}$ & $\mathrm{P}$-value & $\begin{array}{l}\text { Odds Ratio } \\
(95 \% \mathrm{Cl})\end{array}$ & P-value \\
\hline Confirmed Lupus & 0.65 & 0.0019 & $0.38^{1}$ & $<0.0001$ & $1.05^{1}$ & 0.82 \\
\hline $\begin{array}{l}\text { Anticoagulant } \\
\text { antidsDNA (\% positive) }\end{array}$ & $\begin{array}{c}(0.50,0.85) \\
0.82 \\
(0.73,0.91)\end{array}$ & 0.0005 & $\begin{array}{c}(0.24,0.58) \\
0.90^{1} \\
(0.76,1.06)\end{array}$ & 0.19 & $\begin{array}{c}(0.69,1.60) \\
0.66^{1} \\
(0.56,0.79)\end{array}$ & $<0.0001$ \\
\hline Low complement & $\begin{array}{c}0.71 \\
(0.64,0.79)\end{array}$ & $<0.0001$ & $\begin{array}{c}0.71 \\
(0.61,0.83)\end{array}$ & $<0.0001$ & $\begin{array}{c}0.73 \\
(0.620 .86)\end{array}$ & $<0.0001$ \\
\hline $\mathrm{aCL}$ IGG $(\% \text { pos })^{3}$ & $\begin{array}{c}0.26 \\
(0.17,0.39)\end{array}$ & $<0.0001$ & $\begin{array}{c}0.16^{1} \\
(0.09,0.30)\end{array}$ & $<0.0001$ & $\begin{array}{c}0.53^{1} \\
(0.27,1.05)\end{array}$ & 0.069 \\
\hline $\mathrm{aCL}$ IGM (\% pos) ${ }^{3}$ & $\begin{array}{c}0.45 \\
(0.29,0.68)\end{array}$ & 0.0002 & $\begin{array}{c}0.17^{1} \\
(0.09,0.32)\end{array}$ & $<0.0001$ & $\begin{array}{c}2.45^{1} \\
(1.09,5.55)\end{array}$ & 0.032 \\
\hline
\end{tabular}

${ }^{1} \mathrm{P}$-value for difference between Caucasian and African Americans $<0.0001$.

Conclusion: HCQ use was associated with a substantial decline in the rates of positive immunologic biomarkers in SLE patients. The different impact of HCQ in different races suggests the existence of racial differences in SLE subtypes and may indicate the need for different treatment strategies.

References:

[1] Ponticelli C1, Moroni G; Hydroxychloroquine in systemic lupus erythematosus (SLE). Expert Opin Drug Saf. 2017 Mar;16(3):411-419.

Acknowledgments: This work was supported by NIH RO1 AR069572,

Disclosure of Interests: Laurence Magder: None declared, Daniel Goldman: None declared, Michelle A Petri Grant/research support from: GSK, Eli Lilly and Company, Consultant of: Eli Lilly and Company

DOI: 10.1136/annrheumdis-2020-eular.5059

\section{SAT0168 ONLY ONE THIRD OF REAL WORLD LUPUS PATIENTS MEET ELIGIBILITY CRITERIA FOR CLINICAL TRIALS: IMPLICATIONS FOR TRIAL VALIDITY AND GENERALISABILITY}

S. Dyball ${ }^{1}$, S. Collinson ${ }^{2}$, E. Sutton ${ }^{1}$, E. Mccarthy ${ }^{2}$, B. Parker ${ }^{1,2}$, I. N. Bruce ${ }^{1,2}$ on behalf of British Isles Lupus Assessment Group Biologics Register (BILAG-BR) consortium. ${ }^{1}$ The University of Manchester, Manchester, United Kingdom; ${ }^{2}$ The Kellgren Centre of Rheumatology, Manchester, United Kingdom

Background: Despite unprecedented drug development in SLE, the paucity of approved therapies remains a significant challenge. Recent trials have highlighted the need for minimising heterogeneity within SLE populations; however, there is concern this results in the recruitment of patients that are not representative of the SLE population.

Objectives: Our aim was to apply published trial eligibility criteria to patients with non-renal SLE in a large UK-wide register to quantify how accurately these clinical trials represent a real-world cohort.

Methods: A literature review of all major published double-blinded randomised phase III trials in non-renal SLE was performed $(n=12)$. Inclusion and exclusion criteria common across the majority of clinical trials were applied to all patients recruited to the BILAG-BR (BILAG biologics register) starting either biological therapy or standard of care (SOC). We applied available data to common inclusion criteria including age $\geq 18$ years, ACR 1997 SLE classification criteria, positive anti-dsDNA or ANA antibodies, active disease (defined as a BILAG A in 1 domain or a BILAG $B$ in $\geq 2$ domains, or a SLEDAI $\geq 6$ ); and common exclusion criteria including restricted medication rules, active renal or neurological SLE (defined as a BILAG A in either domain), a history of hepatitis B or C, a history of malignancy (excluding basal cell carcinoma), CKD stage 4 or 5 , a UPCR $\geq 100 \mathrm{mg} /$ $\mathrm{mmol}$, and cytopenias (defined as neutrophils $<1.0 \times 10^{9} / \mathrm{L}$, platelets $<10 \times 10^{9} / \mathrm{L}$ or $\mathrm{Hb}<70 \mathrm{~g} / \mathrm{L}$ ). Baseline variables were compared using chi-squared test.

Results: As of July 2018, 837 patients were recruited to the BILAG-BR starting either SOC $(n=125)$ or a biologic therapy $(n=712)$. The commonest biologic and SOC therapy was rituximab $(n=662,93 \%)$ and mycophenolate $(n=64,51 \%)$ respectively. Patients taking SOC were more likely to have inactive disease, as well as having higher steroid doses and less exposure to previous cyclophosphamide or B cell therapy. In the biologic and SOC groups, 476 (67\%) and 71 (57\%) respectively met all inclusion criteria (table 1). One or more exclusion criteria were met by 324 (46\%) of the biologics group and 46 (37\%) of the SOC group. As such, $562(67 \%)$ patients were not eligible to enrol in a clinical trial. The patients not eligible to participate were similar in age $(P=1.0)$, gender $(P=0.7)$ and ethnicity $(p=0.5)$ to those who were eligible. Median disease duration was longer in patients eligible to participate ( 2.9 vs. 5.1 years, $p<0.01$ )

Table 1. Patients from the BILAG-BR who meet eligibility criteria for major SLE clinical trials

\begin{tabular}{lccc}
\hline Inclusion criteria & Biologic $(\mathbf{n}=\mathbf{7 1 2})$ & SOC $(\mathbf{n = 1 2 5})$ & P value \\
\hline Age $\geq 18$ years & 706 & 122 & 0.1 \\
Meet ACR criteria for SLE & 675 & 116 & 0.4 \\
Antibody positive & 567 & 99 & 0.9 \\
Active disease & 626 & 97 & $<0.01$ \\
Total meeting all inclusion criteria & $\mathbf{4 7 6}$ & $\mathbf{7 1}$ & $\mathbf{0 . 0 3}$ \\
Exclusion criteria & Biologic $(\mathbf{n}=\mathbf{7 1 2})$ & $\mathbf{S O C}(\mathbf{n}=\mathbf{1 2 5})$ & $\mathbf{P}$ value \\
Steroids $>40 \mathrm{mg}$ prednisolone & 9 & 8 & $<\mathbf{0 . 0 0 1}$ \\
Active CNS SLE & 39 & 7 & 1.0 \\
Active renal SLE & 138 & 28 & 0.4 \\
Hepatitis B or C & 20 & 1 & 0.2 \\
Malignancy & 52 & 5 & 0.2 \\
Cyclophosphamide $<90$ days before entry & 37 & 0 & $<0.01$ \\
B cell therapy $<1$ year before entry & 50 & 0 & $<0.01$ \\
CKD 4/ 5 & 22 & 3 & 0.7 \\
UPCR $\geq 100$ mg/mmol & 92 & 20 & 1.0 \\
Low blood counts & 25 & 1 & 0.1 \\
Pregnancy & 3 & 1 & 0.6 \\
Total number of patients excluded & $\mathbf{3 2 4}$ & $\mathbf{4 6}$ & 0.1 \\
Total NOT* eligible for clinical trial $(n)$ & $\mathbf{5 6 2 / 8 3 7 ( 6 7 \% )}$ & & 1.0
\end{tabular}

Conclusion: In a large national register of SLE patients, we found that two thirds of patients would not be eligible for recruitment to clinical trials using published inclusion and exclusion criteria. These results suggest that clinical trial recruits are not fully representative of the target disease population. This limits the generalisability of clinical trial results and supports the need for evidence from real world studies to fully understand the effectiveness of new therapies.

Disclosure of Interests: : Sarah Dyball: None declared, Sophie Collinson: None declared, Emily Sutton: None declared, Eoghan McCarthy: None declared, Ben Parker Grant/research support from: GSK and Sanofi Genzyme, Consultant of: GSK, AstraZenaca, UCV, Abbvie, Pfizer, BMS, Celltrion, lan N. Bruce Grant research support from: Genzyme Sanofi, GSK, and UCB, Consultant of: Eli Lilly, AstraZeneca, UCB, Iltoo, and Merck Serono, Speakers bureau: UCB DOI: 10.1136/annrheumdis-2020-eular.2303

\section{SAT0169 HYDROXYCHLOROQUINE PRESCRIPTION PATTERNS IN EUROPE - THE EUROPEAN SURVEY FOR LUPUS PATIENTS (ESLP)}

Z. Osmani ${ }^{1}$, A. Cornet ${ }^{2}$, W. Zacouris-Verweij ${ }^{1}$, S. Frankel ${ }^{2} .{ }^{1}$ LUPUS/APS Committee, Patient Association NVLE, Utrecht, Netherlands; ${ }^{2}$ LUPUS EUROPE, Romford, United Kingdom

Background: Long-term use of hydroxychloroquine (HCQ) is very common in patients with lupus erythematosus. It has been associated with wide-ranging benefits and it is generally well tolerated ${ }^{1}$. However, long-term use (i.e. $>5$ years) and high-dose HCQ (i.e. $>5 \mathrm{mg} / \mathrm{kg} /$ day) are both considered to be risk factors for developing $\mathrm{HCQ}$ retinopathy ${ }^{2}$.

Advances in our understanding of $\mathrm{HCQ}$ retinopathy has led to changes in the recommendations for HCQ dosing and retinopathy screening ${ }^{1-3}$. The latest EULAR guidelines for the management of systemic lupus erythematosus (SLE) ${ }^{4}$ recommend a maximum $\mathrm{HCQ}$ dose of $5 \mathrm{mg} / \mathrm{kg} /$ day and ophthalmological screening at baseline and annually after 5 years of HCQ treatment.

Objectives: To assess whether recent EULAR guidelines regarding $\mathrm{HCQ}$ dosing and retinopathy screening are affecting prescription patterns and screening frequencies in Europe.

Methods: Patients in Europe were given the opportunity to complete the online European Survey for Lupus Patients (ESLP) initiated by LUPUS EUROPE. The survey was promoted on social media from the $26^{\text {th }}$ of June $-11^{\text {th }}$ of July 2019. The survey consisted of 29 questions. Each participant was asked, among other things, to report their body weight $(\mathrm{kg})$, daily $\mathrm{HCQ}$ dose and if they have received baseline screening and/or regular eye examinations.

Results: The online survey was completed by 2938 lupus patients from 36 countries The majority were female $(86.5 \%)$ and diagnosed with SLE $(85.7 \%)$. The daily HCQ dose $(\mathrm{mg} / \mathrm{kg})$ was available from 1678 patients $(57.1 \%)$. The median \pm IQR HCQ dose was $4.3 \pm 2.5 \mathrm{mg} / \mathrm{kg} /$ day with a median treatment duration of 7 years (IQR: $3-14$ ).

The recommended daily $\mathrm{HCQ}$ dose of $5 \mathrm{mg} / \mathrm{kg}$ was exceeded by 618 patients $(36.8 \%)$. Low HCQ dose ( $\leq 4 \mathrm{mg} / \mathrm{kg}$ ) was reported by 769 patients $(45.8 \%)$. In addition, 284 out of 1786 patients (15.9\%) reported they skipped HCQ once a week or more often. Nevertheless, only $8.7 \%$ of patients reported that they were more likely to skip HCQ than other medication. Patients from Belgium, Israel, France and Portugal reported the highest $\mathrm{HCQ}$ dosages. In contrast, patients from Spain reported the lowest $\mathrm{HCQ}$ dosages (Figure 1). 